\title{
The Effect of BI Rate, Exchange Rate, Inflation and Third Party Fund (DPK) on Credit Distribution and Its Impact on Non Performing Loan (NPL) on XYZ Commercial Segment Bank
}

\author{
Jerimieus S Sinaga, Iskandar Muda*, Amlys Syahputra Silalahi \\ Department Master of Management, Universitas Sumatera Utara, Indonesia
}

Received June 26, 2020; Revised August 5, 2020; Accepted August 25, 2020

\begin{abstract}
Cite This Paper in the following Citation Styles
(a): [1] Jerimieus S Sinaga, Iskandar Muda, Amlys Syahputra Silalahi, "The Effect of BI Rate, Exchange Rate, Inflation and Third Party Fund (DPK) on Credit Distribution and Its Impact on Non Performing Loan (NPL) on XYZ Commercial Segment Bank," Universal Journal of Accounting and Finance, Vol. 8, No. 3, pp. 55 - 64, 2020. DOI: 10.13189/ujaf.2020.080301.
\end{abstract}

(b): Jerimieus S Sinaga, Iskandar Muda, Amlys Syahputra Silalahi (2020). The Effect of BI Rate, Exchange Rate, Inflation and Third Party Fund (DPK) on Credit Distribution and Its Impact on Non Performing Loan (NPL) on XYZ Commercial Segment Bank. Universal Journal of Accounting and Finance, 8(3), 55 - 64. DOI: 10.13189/ujaf.2020.080301.

Copyright $\bigcirc 2020$ by authors, all rights reserved. Authors agree that this article remains permanently open access under the terms of the Creative Commons Attribution License 4.0 International License

\begin{abstract}
Along with the level of development of the times, the development of the business world in Indonesia has entered the era of globalization which has resulted in the opening of markets in Indonesia to compete with foreign competitors through trade. Based on the financial ratios and policies of banks that want to review the health of their banks, the measures that must be considered are Macroeconomics, namely the exchange rate, inflation, Central Bank of Indonesia (BI) rate, lending, namely the size of the value of the credit channeled, Collectability is the size of Non-Performing Loans (NPL) and Fund Raising. The Purpose of This Research is to Influence BI Rate, Exchange Rates, Inflation and Third Party Funds (DPK) On Credit Distribution and the Impact on Non-Performing Loans (NPL) At Bank XYZ Commercial Segment. The research method used is a method with a quantitative research approach, while the type of research is descriptive and verification research. To test the research hypothesis, the Path Analysis method is used. Partially the BI rate and Third Party Funds (DPK) have a significant effect on lending, while the exchange rate and inflation have insignificant effects on lending at the commercial segment Bank of XYZ. In addition, the exchange rate and DPK have a significant influence on NPL, while the BI rate, inflation
\end{abstract}

and lending have not significant influence on NPL in the commercial segment Bank of XYZ.

Keywords Profitability, Middle Corporate, Loan to Deposit Ratio, Third Party Funds

\section{Introduction}

One of the benchmarks of national development is economic development in which the economic sector has always been the focus of the government in implementing both short and long term development. Now that the crisis has passed, improving the economic sector remains a top priority. Economic development cannot be separated from the development of various kinds of financial institutions. One of the financial institutions which seems to have the biggest role in economic development is the bank's financial institutions, which are commonly called banks (Syahyunan et al., 2017). At present the lending trend is very tight and difficult, it is indicated by macro and micro economic factors. Now researchers want to examine several macro factors in the form of the effect of exchange 
rates, inflation, the BI rate and a lot of money circulating in the community. Specifically, researchers will conduct research at XYZ Bank by also taking into account the level of Non Performance Loan (NPL) and Loan to Deposit Ratio (LDR). The current assumption is that if the interest rate/BI Rate increases, the people's desire to save is high because they are given high interest with clarity of profit compared to investing their funds in the stock market or in the industry in the real sector. But this is contrary to the people who want to borrow funds from the Bank because it will incur interest on deposit interest (Erwin et al., 2018). Against the increase in interest rates whether there is an influence of public interest in lending funds or vice versa. The assumption of inflation is that there will be an increase in prices. In relation to shares, a sharp increase in the exchange rate of the dollar against the rupiah will negatively impact issuers that have debt in dollars while the issuer's products are sold locally. Meanwhile, export-oriented issuers will receive a positive impact from the increase in the dollar exchange rate. This means that the issuer's share prices that are negatively affected will experience a decline on the Stock Exchange.

At this time many banking companies have built risk management in their companies in an effort to reduce the risk that will occur as a result of lending activities undertaken. To cover the cost of funds, good risk management can help companies avoid as much as possible the costs that must be incurred (Sadalia, 2018). High level of competition among all banks, and the rapid development of the internal and external environment of the bank, the slogan of the principle of "Prudential Banking" was apparently still not able to minimize the losses experienced by banks due to errors in operations and the provision of problem loans whose granting system was influenced by many factors.

The main issues in this study are the factors that influence the NPL ratio in the Commercial segment XYZ Bank. In the Commercial segment XYZ Bank, the average NPL position since 2016 (May) was 5.14\%. This condition is certainly not in accordance with the provisions of $\mathrm{BI}$ which provides a maximum tolerance of NPL is $5 \%$. Nevertheless, it is known that several causes of NPLs can be sourced from internal bank factors such as the quality of human resources, company policies (Erwin et al. 2018) or procedural risk management processes of individual banks (Swamy, 2012). However, a study is still needed to see the causes of NPL from external factors such as the impact of the BI rate, inflation and the exchange rate. The study of the analysis of factors that influence the NPL ratio and the effect on lending is expected to provide an overview of the factors that affect NPL. This research was conducted using the exploratory research approach which aims to find out the factors that influence the NPL ratio and its impact on the XYZ Bank's commercial segment. The limitation and scope of this research is the internal company which covers credit risk towards lending in the Commercial segment XYZ Bank. The types of loans disbursed are the commercial segment, namely productive loans with the authority to process loans above IDR 25 billion and GAS> IDR. 50 billion/month. The objective of this research is to influence the BI rate, exchange rates, inflation and third party funds (DPK) in the distribution of credit and the impact on loans past due (NPL) to the commercial segment of bank XYZ.

\section{Literature Review}

\subsection{Management}

All people must be biased to manage their lives, both in daily life or in the economic sector, in economics, management is often referred to as the science of managing economic activities. Fahmi (2014) explains that management is a process of planning, organizing, leadership and controlling the efforts of organizational members and the use of all organizational resources to achieve the goals set. Management is a process or framework that involves the guidance or direction of a group of people towards organizational goals or tangible goals.

\subsection{Credit}

Banks in carrying out their business activities, credit is the main activity of banks. This is because the most important bank profits come from credit. The definition of credit according to Banking Law Number 10 of 1998 is the provision of money or bills that can be equated with it, based on an agreement or agreement to borrow and borrow between banks with other parties that require the borrower to pay off his debt after a certain period of time with the provision of interest (Kasmir, 2008). Credit provides benefits for banks and borrowers. The advantage for banks is to be able to obtain profits on loan interest paid by the borrower. As for the borrower (debtor), lending can expand its business. Lending to customers is based on a feasibility analysis of the loan application submitted. In order to make decisions on the problems faced in the credit granting process, it is necessary to analyze / assess credit worthiness critically both through qualitative and quantitative approaches to all aspects, both in terms of the micro-economic and macro-economic aspects that affect the customer's business activities. Banks must be able to control the credit risk that is channeled to prospective customers in connection with this. Banks should only provide credit to eligible customers. To be able to ensure that the loans extended are worthy of credit, the bank should conduct a selection process for all incoming credit proposals.

\subsection{Bank Indonesia Rate}

The BI Rate is a reference rate for monetary policy and is 
set at a monthly Board of Governors' Meeting. The BI Rate is a policy interest rate that reflects the stance or monetary policy stance determined by Bank Indonesia and announced to the public. The BI Rate is announced by the Board of Governors of Bank Indonesia at each monthly Board of Governors' Meeting and implemented in monetary operations conducted by Bank Indonesia through liquidity management on the money market to achieve the operational objectives of monetary policy. Taking into account other factors in the economy, Bank Indonesia will generally raise the BI Rate if inflation in the future is estimated to exceed the target set, whereas Bank Indonesia will lower the BI Rate if inflation in the future is estimated to be below the established target (www.bi.go.id). As happened in America, the American Central Bank (The Fed) raised interest rates through monetary policy, when the Fed stimulated the economy. The Fed is lowering interest rates, but the mechanism for lowering interest rates is to increase the money supply. Monetary policy issuing interest rates aims to control the money supply, the interest rate issued by $\mathrm{BI}$ is expected to be responded in the same direction by the company, if the interest rate is raised the expectation is that the deposit rates of commercial banks will also increase, this is where the interest rate function interest controls the circulation of money in society. Another impact of controlling the money supply is to reduce the tendency of people to spend their money, which in turn will reduce the rate of inflation.

\subsection{Exchange Rate}

According to Bussière (2020), the exchange rate (exchange rate) is the exchange between two different currencies, which is a comparison of the value or price between the two currencies. Foreign exchange rates are very dependent on market conditions. In a free market the exchange rate will change following changes in demand and supply (Johnson, 2020). Meanwhile, according to Lahaye and Neely (2020) foreign exchange (foreign exchange) or foreign exchange (forex) is interpreted as a foreign currency and payment instrument used to conduct or finance international financial economic transactions and has an official exchange rate record at the central bank. Can be concluded the exchange rate or foreign exchange (foreign exchange) is the exchange rate of a country's currency against another country's currency used in international financial transactions. Basically, the exchange rate policy set by a country aims to first, maintain balance of payment, with the ultimate goal of maintaining adequate foreign exchange reserves. Second, maintaining the stability of the domestic market so that the exchange rate is not used as a tool for speculation. Third, it functions as a monetary instrument of a central bank that applies the exchange rate as the operational target of monetary policy. In this function the depreciation and appreciation of the exchange rate are used as a means of sterilization and expansion of the money supply. Fourth, it functions as a nominal anchor in controlling inflation.

\subsection{Inflation}

Inflation for the general public, is something that is encountered in everyday life. The level of inflation causes turmoil from time to time even though the level of decline or increase varies. According to Coibion (2020), in the monetary science literature, inflation already has a definite meaning. Basically, what is called inflation (inflation) is a variety of conditions from a continuous increase in the overall price level. Inflation in such a definition is not the same as the short-term 'moment' fluctuations of the general price level. Inflation can affect the distribution of income, allocation of factors of production and national population. The effect on income distribution is called the equity effect, while the effect on the allocation of factors of production and national income is called efficiency and output effects, respectively.

\subsection{Third Party Funds (DPK)}

Sources of funds from other institutions are additional if banks experience difficulties in finding the first and second sources of funds above. These funds are often referred to as party II funds. Searching for this funding source is relatively more expensive and is only temporary. Then the funds obtained from this source are used to finance or pay for certain transactions. Obtaining funds from this source can be obtained from:

a) Liquidity credit from Bank Indonesia.

b) Interbank loans (Call money).

c) Loans from foreign banks.

d) Money Market Securities (SPBU).

The higher the interest rate, the desire to make investments too. The smaller, because the rate of return and use of funds is also getting bigger. Please paraphrase this sentence (Nopirin, 2000). Sources of bank funds are the bank's efforts to raise funds to finance its operations. This is in accordance with its function that the bank is a financial institution where daily activities are in the area of buying and selling money. Of course, before selling money (giving loans), banks must first buy money (raise funds) so that from the difference in interest, the bank is looking for profit. The bank also receives funds from the wider community in the form of: Demand Deposits, Deposits and Savings. Deposits Demand Deposits (Deposits) Deposits at banks whose withdrawals can be made at any time by using checks, other payment orders or by book-entry.

\subsection{Credit Distribution}

Basically, the reason for the community to obtain bank credit facilities is to buy goods, open new businesses, develop businesses both horizontally and vertically, 
rehabilitate, modernize or to meet the needs of emergency working capital (Singh, 2020). The purpose of credit activities carried out by banks is inseparable from the bank's mission, namely profitability and safety. According to Kasmir (2008) the purpose of granting credit is looking for profit, helping the Customer Business, helping the government. Moro (2020) state that some of the benefits obtained by the government from granting credit are (a) tax revenue from profits received by customers and banks. (b) opening up job opportunities because with the expansion of the business it requires a lot of manpower. (c) increase the amount of goods and services circulating in the community.

\subsection{Non Performing Loans (NPL)}

Every bank in carrying out its business activities as a financial institution that gives credit to debtors will surely face a risk. Erwin (2018) states that, business risk or business risk bank is a level of uncertainty about the expected revenue to be received. Revenues in this case are bank profits. The higher the uncertainty of income earned by a bank, the more likely the risk faced and the higher the risk premium or desired interest. Credit risk or often also referred to as default risk is a risk due to failure or inability of customers to return the loan amount obtained from the bank in accordance with the interest in accordance with a predetermined or scheduled period. Non Performing Loan (NPL) is a comparison between non-performing loans and total loans (Rezina et al., 2020). Khafid and Anisykurlillah (2020) states that non-performing loans or problem loans can be interpreted as loans that have difficulty in repayment due to deliberate factors and/or due to external factors beyond the control capabilities of the debtor. Kasmir (2018) revealed that the granting of a credit facility carries a risk of being stalled. As a result, credit cannot be billed, causing losses to be borne by a bank.

\section{Methods}

This type of research is quantitative research. Quantitative research attaches importance to the variables as research objects and these variables must be defined in terms of the operational of each variable and understanding from the outside. Quantitative research requires the existence of a hypothesis and testing which will then determine the next steps, such as determining the technical analysis and statistical formula that will be used. While the nature of this research is explanatory. Explanatory research is to test hypotheses that state a causal relationship between two or more variables. Data collection technique is a method/documentation study conducted by collecting data derived from documents in the form of monthly reports on the achievement/ distribution of credit, funds and collectability reports from 2015-2018 at PT Bank XYZ Commercial segment and macroeconomic data virtually through the site Bank Indonesia's official website, http://www.bi.go.id. Data collected from all Bank XYZ Branch Offices throughout Indonesia includes all Bank XYZ branch offices that distribute commercial segment loans for the period of 2015-2018 totaling 24 Regional Offices throughout Indonesia. The test was conducted at Bank XYZ because it was the largest bank in Indonesia in terms of assets and in terms of the amount of credit expansion. For the research model show in Figure 1:

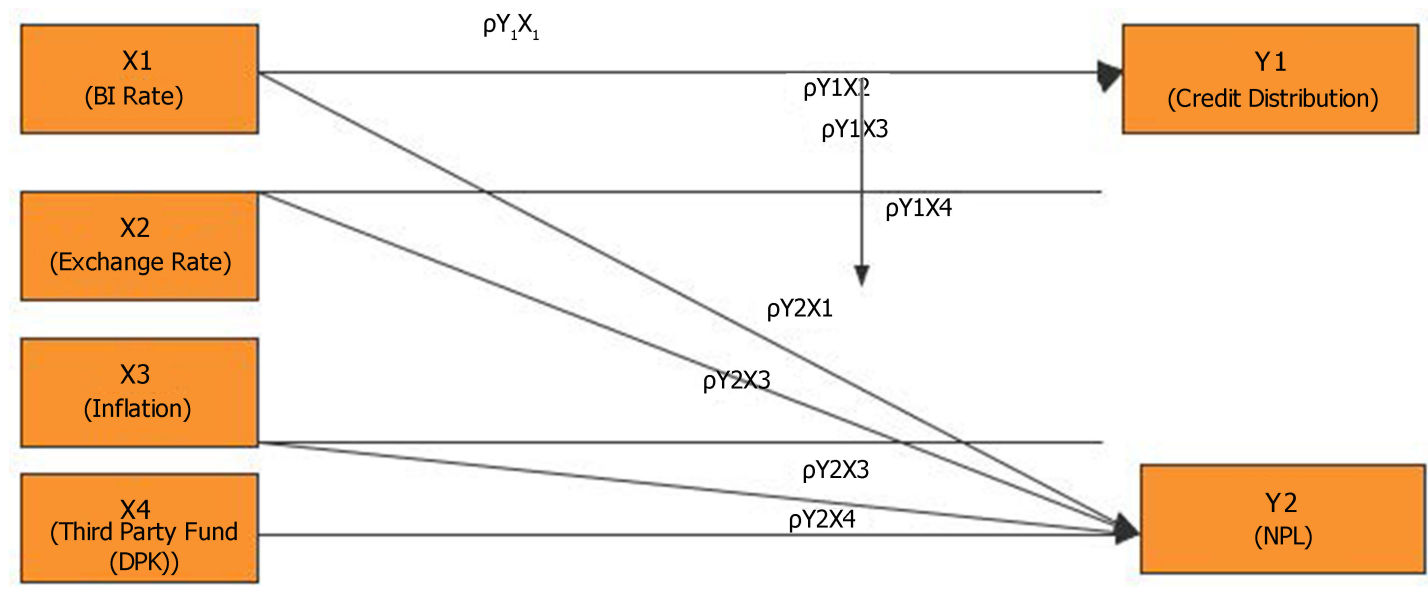

Figure 1. Research Model 
Model Equation:

$\mathrm{Y}_{1}=\rho_{\mathrm{Y} 1 X 1} \mathrm{X}_{1}+\rho_{\mathrm{Y} 1 \mathrm{X} 2} \mathrm{X}_{2}+\rho_{\mathrm{Y} 1 \mathrm{X} 3} \mathrm{X} 3+\rho_{\mathrm{Y} 1 \mathrm{X} 4} \mathrm{X} 4+\varepsilon_{1}$

$\mathrm{Y}_{2}=\rho_{\mathrm{Y} 2 \mathrm{X} 1} \mathrm{X}_{1}+\rho_{\mathrm{Y} 2 \mathrm{X} 2} \mathrm{X}_{2}+\rho_{\mathrm{Y} 2 \mathrm{X} 3} \mathrm{X}_{3}+\rho_{\mathrm{Y} 2 \mathrm{X}_{4} \mathrm{X}_{4}}+\rho_{\mathrm{Y} 2 \mathrm{Y} 1} \mathrm{Y}_{1}+\varepsilon_{2}$

$\mathrm{Y}_{1}=$ Credit Distribution

$\mathrm{Y}_{2}=$ Non-Performing Loans

$\mathrm{X}_{1}=$ Central Bank of Indonesia (BI rate)

$\mathrm{X}_{2}=$ Exchange Rates

$\mathrm{X}_{3}=$ Inflation

$\mathrm{X}_{4}=$ Third Party Funds (DPK)

The coefficient of determination test is done with a view to seeing how much influence the changes in the independent variables used in the model are able to explain their influence on the dependent variable. This test looks at the coefficient of Determination (R2) obtained from the estimated equation. $t$ statistic testing is used to test the partial effect of the independent variables on the dependent variable. This test is done by comparing the calculated $t$ value with the $t$ table value. $t$ test was carried out for the direct influence variable (model 1) and the indirect effect (model 2). The results of using the regression analysis model can be done with the consideration that there are no violations of the classical assumptions.

\section{Result and Discussion}

\subsection{Result}

To find out the relationship between exogenous variables namely interest rates, exchange rates, inflation, deposits against endogenous variables, namely lending and NPLs at XYZ Bank, the Path Analysis model was used. The extent to which the data available in proving hypotheses will be explained in calculations and tests of each regression coefficient obtained using computer aids using the Eviews 6.0 program. Equation Model 1 (Credit Distribution as an Independent variable). The regression model is as follows in Figure 2:

$$
\ln Y_{1}=\beta_{0}+\beta_{1} \ln X_{1}+\beta_{2} \operatorname{LnX}_{2}+\beta_{3} \ln X_{3}+\beta_{4} \operatorname{Ln} X_{4}+\mu
$$

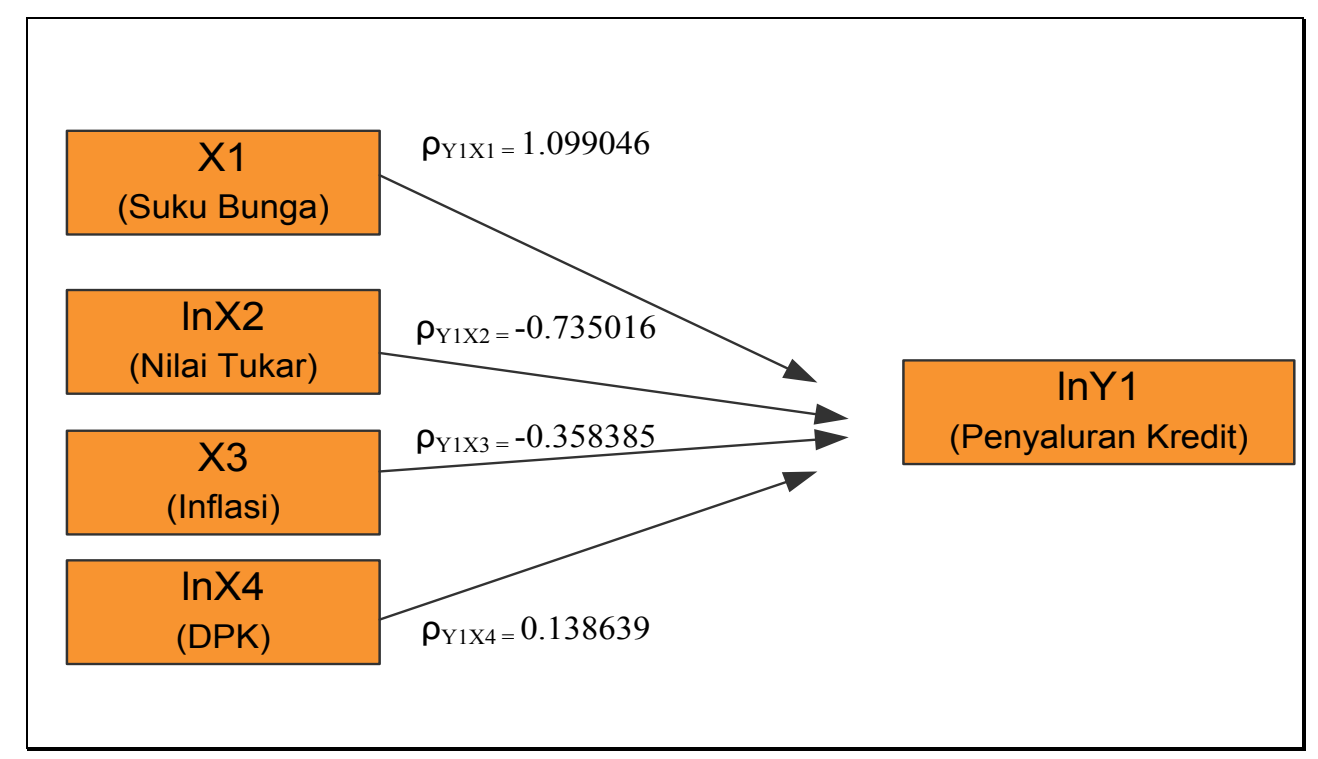

Figure 2. First Equation

Test to produce $t$ Table with Excel as follows in Table 1:

Table 1. t-table

\begin{tabular}{|c|c|c|c|c|}
\hline \multirow{2}{*}{ Equation } & \multirow{2}{|c|}{$\alpha$} \\
\cline { 3 - 5 } & Degree of freedom (df) & $1 \%$ & $5 \%$ & $10 \%$ \\
\hline Model 1 & $\mathrm{n}-\mathrm{k}=48-4=44$ & 2.6923 & 2.0154 & 1.6802 \\
\hline
\end{tabular}

Source: Microsoft Excel output (reprocessed)

While the results of testing independent variables on the dependent variable are in the following Table 2: 

and Its Impact on Non Performing Loan (NPL) on XYZ Commercial Segment Bank

Table 2. Regression Results Factors Affecting Credit Distribution at XYZ Bank

Dependent Variable: LNY1

Method: Least Squares

\begin{tabular}{cccc}
\hline \hline Variable & Coefficient & t-Statistic & Explanation \\
\hline \hline C & & & \\
LNX1 & 17.36050 & 13.34793 & Significant on $\alpha=1 \%$ \\
LNX2 & 1.099046 & 1.926321 & Significant on $\alpha=10 \%$ \\
LNX3 & -0.735016 & -4.960601 & Significant on $\alpha=1 \%$ \\
LNX4 & -0.358385 & -0.667062 & Not Significant \\
R-squared & 0.138639 & 4.810397 & Significant on $\alpha=1 \%$ \\
\hline \hline Adjusted R-squared & & & \\
F-statistic & 0.470883 & & \\
Prob(F-statistic) & 0.421663 & & \\
& 9.566876 & & \\
\hline
\end{tabular}

Source: E-Views output (reprocessed) $\mathrm{n}=$ number of observations, $\mathrm{k}=$ number of independent variables

The form of equation Model 1 based on Table 2 as a follows :

$\beta_{1=} \rho_{\mathrm{Y} 1 X 1}=1.099046$

$\beta_{2}=\rho_{\mathrm{Y} 1 \mathrm{X} 2}=-0.735016$

$\beta_{3}=\rho_{\mathrm{Y} 1 \mathrm{X} 3}=-0.358385$

$\beta_{4}=\rho_{\mathrm{Y} 1 \mathrm{X} 4}=0.138639$

Equation Model 2 (NPL as an Independent variable)

$$
\ln Y 1_{t}=17.36050+1.099046\left(X 1_{t}\right)-0.735016\left(\ln X_{2 t}\right)-0.358385\left(X 3_{t}\right)+0.138639\left(\ln X 4_{t}\right)
$$

The regression model is as follows:

$$
\ln Y_{2}=\beta_{0}+\beta_{1}\left(\ln X_{1}\right)+\beta_{2}\left(\ln X_{2}\right)+\beta_{3}\left(X_{3}\right)+\beta_{4}\left(\ln X_{4}\right)+\beta_{5}\left(\ln Y_{1}\right)+\mu
$$

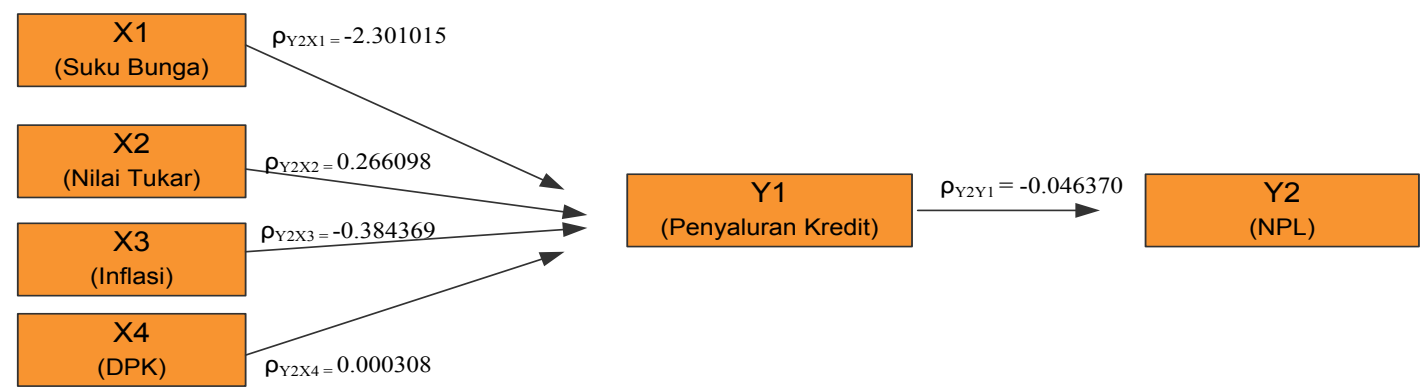

Figure 3. Second Equation

Test to produce $t$ Table with Excel as follows in Table 2:

\begin{tabular}{|c|c|c|c|c|}
\hline Equation & Degree of freedom (df) & \multicolumn{3}{|c|}{$\alpha$} \\
\hline Model 2 & $n-k=48-5=43$ & 2.6951 & 2.0167 & 1.6811 \\
\hline
\end{tabular}

Table 3. t-table Value

Source: Microsoft Excel output (reprocessed)

While the results of testing independent variables on the dependent variable are in the following Table 4: 
Table 4. Regression Results Factors Affecting NPLs at XYZ Bank

Dependent Variable: LNY2

Method: Least Squares

\begin{tabular}{cccc}
\hline \hline Variable & Coefficient & t-Statistic & Explanation \\
\hline \hline C & -1.762814 & -1.772571 & Significant on $\alpha=10 \%$ \\
LNX1 & -2.301015 & -11.47703 & Significant on $\alpha=1 \%$ \\
LNX2 & 0.266098 & 4.248027 & Significant on $\alpha=1 \%$ \\
LNX3 & -0.384369 & -2.111059 & Significant on $\alpha=5 \%$ \\
LNX4 & 0.000308 & 0.025530 & Not Significant \\
LNY1 & -0.046370 & -0.901872 & Not Significant \\
R-squared & 0.912102 & & \\
Adjusted R-squared & 0.901638 & & \\
F-statistic & 87.16545 & & \\
Prob(F-statistic) & 0.000000 & & \\
\hline
\end{tabular}

Source: E-Views output (reprocessed) $n$ = number of observations, $k=$ number of independent variables

The form of equation Model 2 based on Table 4 as a follows :

$$
\begin{gathered}
\beta_{1=} \rho_{\mathrm{Y} 2 \mathrm{X} 1=-2.301015} \\
\beta_{2}=\rho_{\mathrm{Y} 2 \mathrm{X} 2}=0.266098 \\
\beta_{3}=\rho_{\mathrm{Y} 2 \mathrm{X} 3}=-0.384369 \\
\beta_{4}=\rho_{\mathrm{Y} 2 \mathrm{X} 4}=0.000308 \\
\beta_{5}=\rho_{\mathrm{Y} 2 \mathrm{Y} 1}=-0.046370 \\
\mathrm{Y} 2_{\mathrm{t}}=-1.762814-2.301015\left(\mathrm{X} 1_{\mathrm{t}}\right)+0.266098\left(\mathrm{LNX} 2_{\mathrm{t}}\right) \\
-0.384369\left(\mathrm{X} 3_{\mathrm{t}}\right)+0.000308-\left(\mathrm{X} 4_{\mathrm{t}}\right)-0.901872\left(\mathrm{Y} 1_{\mathrm{t}}\right)
\end{gathered}
$$

Direct Effect/direct influence

Model 1 interpretation:

The estimation results above can be explained by the influence of the BI rate variable, exchange rate, inflation, third party funds on lending in the commercial segment $\mathrm{XYZ}$ Bank as follows:

\section{1) BI Rate $\left(X_{1}\right)$}

BI Rate $\left(\mathrm{X}_{1}\right)$ has a positive effect on lending with a coefficient of 1.099046. This means that if there is an increase in the BI Rate by $1 \%$, it will cause an increase/increase in lending in the commercial segment XYZ Bank by $1,099046 \%$.

\section{2) Exchange Rates $\left(X_{2}\right)$}

Exchange Rate $\left(\mathrm{X}_{2}\right)$ has a negative /opposite effect on lending with a coefficient of -0.735016 . This means that if an exchange rate increases by $1 \%$, it will cause a decrease in lending in the XYZ Bank commercial segment by $-0.735016 \%$.

\section{3) Inflation $\left(X_{3}\right)$}

Inflation $\left(\mathrm{X}_{3}\right)$ has a negative/opposite effect on lending with a coefficient of -0.358385 . This means that if there is an increase in inflation of $1 \%$ it will cause a decrease in lending in the XYZ Bank commercial segment by $-0.358385 \%$.

\section{4) DPK (X4)}

DPK $\left(\mathrm{X}_{4}\right)$ has a positive influence on lending with a coefficient of 0.138639 . This means that if there is an increase in deposits by $1 \%$, it will cause an increase/increase in lending in the commercial segment XYZ Bank by 0.138639 .

\subsection{Discussion}

\subsubsection{Discussion of BI Rate Results on Credit Distribution}

The influence of the BI rate on lending can be seen in Table 4. From the results of this test it was found that the effect of the BI rate directly on credit distribution has an influence with a coefficient of 1.09 where the increase in the BI rate will have an impact on the increase in lending in the commercial segment. The results of the study are supported by research conducted by Hariemufti (2019), Kosasih (2019), Mubin (2020), which state that interest rates have a positive and not significant effect on credit. This indicates that the current interest rate is not too much of a concern by customers because even though interest rates are rising, customers will continue to make loans to banks on the grounds of meeting their daily needs. So that the size of the lending granted by foreign national private commercial banks (BUSN) is not influenced by the high and low credit interest rates. The results of this study contradict the research conducted by Andhikatama (2020) which stated that credit interest rates had a negative and 
significant effect on credit.

\subsubsection{Discussion on the Results of Exchange of Credit on Credit Distribution}

The effect of exchange rates on lending can be seen in Table 4. The results of this test it was found that the effect of the exchange rate directly on lending has a negative influence with a coefficient of 0.73 where the increase in the exchange rate will have an impact on the increase in lending in the commercial segment. For the exchange rate, the bank will have a risk of loss when the bank has a net asset or net liability position in foreign currency that is not in accordance with the expected value. In this study, the exchange rate variable has a negative effect on lending. This supports the statement made by Basel (2004), where market risk consists of interest and exchange rate risk arising from the movement of market variables from bank portfolios which can cause losses to banks, then losses caused by exchange rates are caused by opposite movement of the bank's exchange rate when the bank has an open position (Andrle, 2019). Likewise, with research conducted by Sinaga (2000) who examined the depreciation of the Rupiah which resulted in the ability of the debtor, especially foreign currency loans, which finally described the bank experiencing a negative spread, where the debtor's ability is not offset by changes in exchange rates.

\subsubsection{Discussion of DPK Results on Credit Distribution}

The influence of DPK on lending can be seen in Table 4. From the results of this test it was found that the influence of DPK directly on lending has a positive effect with a coefficient of 0.13 where the increase in deposits will have an impact on the increase in lending in the commercial segment. Based on the results of tests on the influence of DPK on credit shows that Third Party Funds have a positive and significant effect on credit, this is consistent with the theory of credit. The higher the Third Party Funds successfully collected by banks, the higher the ability of a bank to extend credit, because the largest source of funds obtained by banks for lending is from collecting deposits. This is due to the fact that Third Party Funds are one of the sources of bank funds that have been collected from the community, which later must be channeled back in the form of credit. This is in line with the function of banks as financial intermediaries. The results of this study are in line with research from Muda (2019) and Naritomi (2019), which states that Third Party Funds (DPK) have a positive and significant effect on credit.

\subsubsection{Discussion of BI Rate Results on NPLs}

The influence of the BI rate on NPLs can be seen in Table 4. From the results of this test it was found that the effect of the BI rate directly on the NPL has a negative effect with a coefficient of 2.30 where the increase in the BI rate will have an impact on the decline in NPLs. Based on the results of tests on the influence of DPK on credit shows that Third Party Funds have a positive and significant effect on credit, this is consistent with the theory of credit. The higher the Third Party Funds successfully collected by banks, the higher the ability of a bank to extend credit, because the largest source of funds obtained by banks for lending is from collecting deposits. This is due to the fact that Third Party Funds are one of the sources of bank funds that have been collected from the community, which later must be channeled back in the form of credit. This is in line with the function of banks as financial intermediaries.

\subsubsection{Discussion on Results of Credit Distribution to NPLs}

The effect of lending on the NPL can be seen in Table 4 . From the results of this test it was found that the effect of lending directly on NPL had a negative effect with a coefficient value of 0.04 which did not have a significant effect. Credit has a negative and not significant effect on Non-Performing Loans (NPL). This indicates that if the NPL is high, the available funds are small, with the funds available small, the bank does not have the capital to be distributed to the public, so that the cash flow is hampered so that the bank cannot provide large amounts of credit to customers. The results of this study are supported by research conducted by Al-Wesabi (2020) who stated that NPL has a positive and not significant effect on credit. There have been many efforts undertaken by banks to prevent NPLs such as prudent credit policies, strict credit risk management and competency development or technical training for credit managers. But due to various business environment reasons or debtor management capabilities, NPLs are still experienced by a bank. A declining economy, sluggish industry or declining consumer purchasing power can be a pressure that drives an increase in NPLs. In addition, the debtor's character or integrity that becomes bad can be a factor causing NPLs even though his business is still running smoothly. Thus it can be said that NPL tends to be unpredictable and avoided by banking companies because it is an inherent risk. There is a possibility that if a high NPL can be caused by the current global economic conditions or when the NPL of a banking company is in a high condition, the company will continue to channel large amounts of credit because lending is one of the company's facilities for profit, because it is supported by increase in Third Party Funds (DPK). The results of this study contradict the research conducted by Casabianca (2020) which stated that NPL had a negative and significant effect on credit.

\section{Conclusions and Suggestions}

\subsection{Conclusions}

Based on the analysis of the conclusions obtained as 
follows:

1. Partially the BI rate and DPK have a significant effect on lending, while the exchange rate and inflation have an insignificant effect on lending at the commercial segment Bank XYZ.

2. Partially the exchange rate and third party funds have a significant influence on NPL while the BI rate, inflation and lending have insignificant effect on NPL in the commercial segment Bank XYZ.

\subsection{Suggestions}

Based on the analysis description, obtained suggestions or input as follows:

1. With the increase in the BI rate set by the regulator, it is expected that the Bank will remain aggressive in its expansion, based on this research, lending will also increase.

2. Banks can take the strategy of increasing the number of deposits, will have an impact on increasing lending.

3. Banks are expected to have a strategy to maintain an increase in NPLs by taking into account the increase in the exchange rate/exchange rate and DPK.

4. Banks can continue to extend credit even though NPLs, BI rates and inflation have increased due to their insignificant influence.

5. The role of Bank Indonesia to maintain the stability of the $\mathrm{BI}$ rate, exchange rate and inflation is expected to increase supervision in intervening so that companies can benefit and can project future income and banks can channel loans with low NPLs.

6. The government is expected to maintain the stability of economic fundamentals in the form of the BI rate, the exchange rate and inflation to increase investors in doing business in the commercial segment.

The contribution of this study is for academics to provide additional repertoire of similar research and provide empirical evidence related to the influence of macroeconomic (BI rate, exchange rate and inflation) on non-performing loans (NPL) as well as its impact on lending in commercial segment XYZ banks, whether in line or not with similar research before. For bank management to be input in making policies related to funding/liquidity management, macroeconomic movement and lending to maintain the NPL ratio.

\section{Acknowledgement}

Thanks to the funders of this research as Master/Thesis Grant research from the Director of Research and Community Service (DRPM) of the Republic of Indonesia in 2020 .

\section{REFERENCES}

[1] Al-Wesabi, H. A. (2020). Credit risk of Islamic banks in GCC countries. International Journal of banking and finance, $10(2), 95-112$.

[2] Andhikatama, A. (2020). Factors Affecting Profitability with The Interest Rate as Moderating Variables in Bank Sumut. International Journal of Public Budgeting, Accounting and Finance, 3(1). 33-40. Retrieved from http://Ijpbaf.Org/Index.Php/Ijpbaf/Article/View/235>. Accessed on 13 June 2020

[3] Andrle, M., Brada, J. C., Tomšík, V., \& Vlček, J. (2019). Banks' Adjustment to Basel III Reform: A Bank-Level Perspective for Emerging Europe. Eastern European Economics, 57(1), 50-69.

[4] Basel, I. I. (2004). International convergence of capital measurement and capital standards: a revised framework. Bank for international settlements. Bank for international settlements. Basel.

[5] Bank of Indonesia (2020). Retrieved from www.bi.go.id. Acceses on March 20, 2019.

[6] Bussière, M., Gaulier, G., \& Steingress, W. (2020). Global trade flows: Revisiting the exchange rate elasticities. Open Economies Review, 1-54.

[7] Casabianca, E. J. (2020). Credit Supply Response to Non-Performing Loans: Some Evidence from the Italian Banking System. Journal of Applied Finance and Banking, 10(4), 43-67.

[8] Coibion, O., Gorodnichenko, Y., \& Ropele, T. (2020). Inflation expectations and firm decisions: New causal evidence. The Quarterly Journal of Economics, 135(1), 165-219.

[9] Erwin, K., Abubakar, E., Muda, I. (2018). The relationship of lending, funding, capital, human resource, asset liability management to non-financial sustainability of rural banks (BPRs) in Indonesia. Journal of Applied Economic Sciences, Volume XIII, Spring 2(56). 520 - 542

[10] Fahmi, I. (2014). Banks \& Other Financial Institutions Theories and Applications. Bandung: Alfabeta.

[11] Hariemufti, Y. (2019). Effect of Credit Risk, Liquidity Risk, Interest Rate Risk And Capital On Public Banking Profitability Listed In Indonesia Stock Exchange (IDX). International Journal of Public Budgeting, Accounting and Finance, 2(1), 1-8. Acceses on $<$ http://ijpbaf.org/index.php/ ijpbaf/article/view/135>. Date accessed: 12 February 2020.

[12] Johnson, O. E. (2020). Establishing Socially Efficient Foreign Exchange Markets. In Financial Sector Development in African Countries (pp. 79-102). Palgrave Pivot, Cham.

[13] Kasmir, (2008). Analysis of Financial Statements, Rajawali Press Publisher, Jakarta.

[14] Khafid, M., \& Anisykurlillah, I. (2020). Investigating the Determinants of Non-Performing Loan: Loan Monitoring As a Moderating Variable. KnE Social Sciences, 126-136.

[15] Kosasih, E., Matondang, I. N., \& Wibowo, R. P. (2019). The Factors Affecting Decisions for Use of Credit Services (Case 
Study in XYZ Bank, Enterprise Banking Segment). International Journal of Research and Review, 6(7), 513-522.

[16] Lahaye, J., \& Neely, C. (2020). The role of jumps in volatility spillovers in foreign exchange markets: meteor shower and heat waves revisited. Journal of Business \& Economic Statistics, 38(2), 410-427.

[17] Moro, A., Maresch, D., Fink, M., Ferrando, A., \& Piga, C. (2020). Spillover effects of government initiatives fostering entrepreneurship on the access to bank credit for entrepreneurial firms in Europe. Journal of Corporate Finance, 101603.

[18] Mubin, M. K., \& Purwono, R. (2019). Analysis of Relationship between Third Party Funds and Interest Rate with Distribution of Investment Credits and Working Capital Credit by Commercial Banks in Indonesia. Journal of Advances in Social Science and Humanities, 5(2), 616-621.

[19] Muda, I., Erlina, Diharja, M.P., Omar, N.H., Said, J. (2019). The role of institutional ownership in strengthening to the enterprise value on the banking issuers. Banks and Bank Systems. 14(1). 42-54.

[20] Naritomi, J. (2019). Consumers as tax auditors. American Economic Review, 109(9), 3031-72.

[21] Nopirin (2000). Monetary Economics. Book I. Yogyakarta: BPFE UGM.
[22] Rezina, S., Chowdhury, R. S., \& Jahan, N. (2020). Non-Performing Loan in Bangladesh: A Comparative Study on the Islamic Banks and Conventional Banks. Indian Journal of Finance and Banking, 4(1), 76-83.

[23] Sadalia, I, M. H. Kautsar, and N. Irawati (2018). Analysis of the efficiency performance of Sharia and conventional banks using stochastic frontier analysis. Banks and Bank Systems, 13(2), 27-38. doi: 10.21511/bbs.13(2).2018.03.

[24] Sinaga, M.S. (2018). Analysis of Influence of Tariff of Import Duty, Exchange Rate, Import Value and Import Volume on Income of Import Duty in Indonesia with Free Trade Agreement as Moderating Variable. International Journal of Public Budgeting, Accounting and Finance, 1(2), 1-13. Retrieved from Http://Ijpbaf.Org/Index.Php/Ijpbaf/Ar ticle/View/39>. Accessed on 13 June 2020.

[25] Singh, K. (2020). Credit ratings of power distribution utilities in northern region of India. Asian Journal of Economics, Finance and Management, 11-19.

[26] Syahyunan, Muda' I, Siregar, H.S, Sadalia, I. \& Chandra' G. (2017). The Effect of Learner Index and Income Diversification on The General Bank Stability in Indonesia. Banks and Bank Systems. 12(4). 171-184.

[27] Swamy, P.M., Vighneswara (2012). Financial Instability, Uncertainty and Banks' Lending Behaviour (August 8, 2012). Available at SSRN: https://ssrn.com/abstract $=2126$ 772 or http://dx.doi.org/10.2139/ssrn.2126772 